RAIRO-Inf. Theor. Appl. 39 (2005) I-VII

DOI: $10.1051 /$ ita:2005020

\title{
PREFACE
}

The present volume is a tribute to Imre Simon, on the occasion of his 60th birthday; the volume consists of contributions from Imre's friends, colleagues and students.

\section{IMRE'S EARLY YEARS}

Imre was born on August 14, 1943 in Budapest, Hungary, where he spent the first thirteen years of his life. He attended the local primary school on "Sziget Utca" and then the high school on "Szemere Utca" where he already enjoyed discussing mathematics with his teacher. After the brutal repression of the "Hungarian revolution" in 1956, some 200000 people left the country. Since Imre's youngest brother was only one year old, his family did not want to take the chance of emigrating clandestinely. Instead, they waited until they eventually received an emigration permit and then a visa to Brazil. They chose Brazil, because it was one of the countries accepting immigrants and because Imre's uncle was living there. They left Europe from the port of Genoa, Italy, in June 1957. Imre recalls that the day before they embarked, the family wanted to enjoy a nice Italian meal in the city. In order to find his way back to the hotel, Imre's father wrote down a word he had seen on the wall of the hotel so that he could unambiguously determine its location; the word was albergo! Due to his precocious expertise with words and information theory, however, Imre was able to make good use of this small piece of information and lead his family safely back to the hotel.

Once in Brazil, the family started taking private lessons in Portuguese. Within a few months, Imre was able to successfully pass the examinations that allowed him to attend the Colégio Rio Branco high school in the city of São Paulo. Because the school calendars have a difference of six months in the two hemispheres, Imre lost no time in the process.

\section{THE YEARS OF TRANSITION}

In 1962, he entered the Escola Politécnica da Universidade de São Paulo (rank 17). There he had his first experience with computers (an IBM 1620) and, along with other students of his generation (among them Tomasz Kowaltowski and Claudio Lucchesi), he served at the Centro de Computação of the University of São Paulo. They implemented the first computerized entrance exams (vestibulares) for the medical schools in the state of São Paulo. Also at that time he was commissioned by the Secretary of Treasury Delfim Netto to write a program computing the index numbers for estimating the inflation rate - in those years, Brazil had a 3-digit 
annual inflation rate. This was quite an achievement considering that the memory of the computer had only 20000 decimal digits.

After graduating in Electrical Engineering with a major in Electronics in 1966, he won in 1969 a grant from FAPESP (Fundação de Amparo to Pesquisa do Estado of São Paulo), and received a research assistantship from the University of Waterloo, Canada, for his PhD studies. In 1972 he completed his PhD thesis entitled "Hierarchies of Events with Dot-Depth One" under the supervision of Janusz (John) Brzozowski. He was the first of several graduate students from Brazil at Waterloo. Later, an exchange agreement was signed between Brazil and Canada, and Waterloo benefitted by attracting several other bright students from Brazil, and eventually also from other South American countries. Many of those graduates are now senior researchers in their home Universities. After his $\mathrm{PhD}$ studies, Imre returned to Brazil to become a faculty member at the Instituto de Matemática e Estatística da Universidade of São Paulo (USP), where he has remained until the present time, except for short visits to various universities around the world.

\section{IMRE'S VISION OF COMPUTER SCIENCE}

Imre sees theory and practice in Computer Science as completely intertwined. As an example of this, he would give the Unix "diff" command, whose design requires both theoretical expertise and experimental knowledge. His solution to the problem of pattern matching uses an automaton whose size is independent of the input alphabet; this is another illustration of Imre's approach. Also, although his major result in the theory of varieties uses sophisticated tools of the algebraic theory of finite semigroups, he nonetheless constantly strove to improve one of the steps of his proof: the algorithm for distinguishing two words by their subwords. His communication to the WORD 2003 conference held in Turku, Finland, is a very efficient algorithm for solving this problem.

At the heart of Imre's research is combinatorics of words. His characterization of the piecewise testable languages fits in this area, as well as his proof of Higman's number-theoretic theorem, and his investigation of the performance of the Ziv and Lempel compression algorithm whose explicit aim is to substitute a purely combinatorial approach for the more classical techniques of probability theory.

\section{IMRE'S CONTRIBUTIONS TO SCIENCE}

Imre made significant contributions to the theory of varieties of languages. Several of us remember the fascination of the late Samuel Eilenberg with Imre's new proof of the piecewise testable languages at the Spring School organized by the Laboratoire d'Informatique Théorique et Programmation (LITP) in 1975 at Vicsur-Cère, France. The use of the structure of the so-called tropical semiring, which enabled Imre to nicely formalize the finite power property and eventually solve the problem in an elegant way, is also to his credit. This notion was known in the area of control of discrete systems, but it was Imre who introduced it to Computer Science. Deep results on this structure were later discovered, giving evidence to the importance of the concept. Imre also contributed to the recent progress in the Burnside Problem for semigroups. But Imre contributed to the progress of Science 
not only through his personal research; he also played a major role in building a strong school of Computer Science in Brazil.

Imre writes each of his papers extremely carefully. They can be used as material for a course on technical writing. (One could argue that badly written papers serve the same purpose, by showing how not to write. Well-written papers are, unfortunately, much more rare than badly-written ones!) He decomposes the difficulty of a problem until each step makes sense, can be understood by itself, and often can be applied in other contexts. A typical example is Imre's paper on the decidability of the finiteness of a semigroup of matrices over the tropical semiring, or the graph theoretic theorem in the proof of the piecewise testable languages. A paper by Imre always teaches more than is required just to solve a problem. This care is sometimes excessive, in that he neglects to publish some of his results, to the dismay of his friends. One of us recalls a talk given in 1989 at the University of Waterloo on Imre's manuscripts dating back to the early seventies and since left unpublished.

\section{OTHER ACTIVITIES}

In addition to his purely scientific activities, Imre has held several administrative positions. In particular, he was the Chair of the Central Commission on Informatics of the University of São Paulo during the period 1994-98. During his tenure, the computing facilities were decentralized and the different units of the university were connected through a high-speed local network. For the last six years, jointly with colleagues from the Humanities, Imre has been leading an interdisciplinary group studying the impact of the new technologies of information on society and on the university.

Imre is also a member of the Coordinating Commission of the TIDIA, Tecnologia da Informação no Desenvolvimento da Internet Avançada (Technology of Information for the Development of Advanced Internet). This is a program supported by FAPESP, the Research Foundation of the State of São Paulo.

\section{AWARDS AND PRIZES}

Imre Simon was awarded several prizes. In 1979 he received the Jabuti Prize of Exact Sciences. In 1989, he was rewarded, together with M. Gromov (IHES, France) and J. Steglitz (Stanford University), the Union d'Assurance de Paris (UAP) Prize, France. In 1996, he was honoured with the Ordem Nacional do Mérito Científico in the category Grã-Cruz, in the section of Mathematical Sciences.

In 1980 he became a member of the Academy of Sciences of the State of São Paulo and in 1981 a full member of the Brazilian Academy of Sciences in the area of Mathematical Sciences.

Christian Choffrut

YOSHIKO WAKABAYASHI 


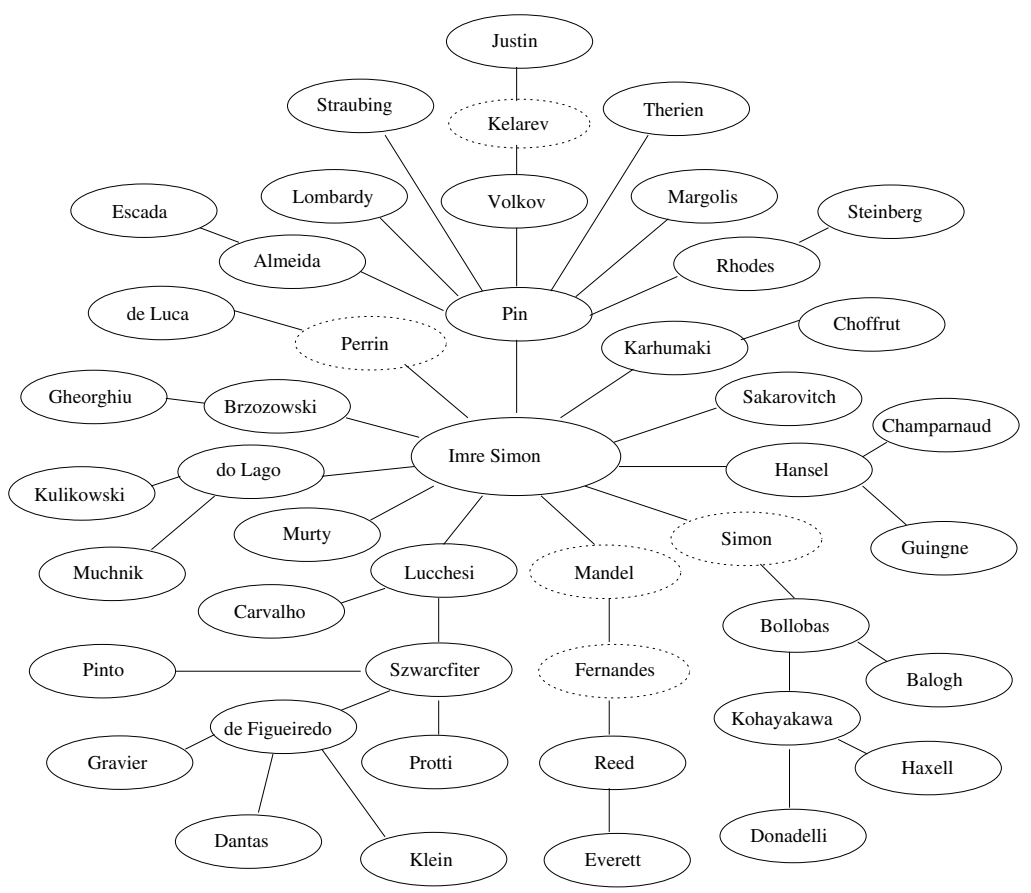

Figure : The tree is a subgraph of the collaboration graph containing Imre Simon and the authors of the contributed papers of this volume, indicated in the solid vertices. The dotted vertices correspond to researchers who do not have a paper in this volume, but are essential in the shortest path between Imre Simon and the contributors to this volume. Observe that more than half of the authors are at distance at most two of Imre Simon.

\section{SCIENTIFIC WRITINGS}

[1] J.A. Brzozowski and I. Simon, Characterizations of locally testable events, in Proceedings of the 12th Annual Symposium on Switching and Automata Theory. Piscataway, NJ, IEEE (1971) $166-176$.

[2] J.A. Brzozowski and I. Simon, Characterizations of locally testable events. Discrete Math. 4 (1973) 243-271.

[3] U.G. Cordani and I. Simon, A obra e o legado de John von Neumann. Estudos Avançados 26 (1996) 175-177.

[4] Z. Ésik and I. Simon, Modeling literal morphisms by shuffle. Semigroup Forum 56 (1998) 225-227. 
[5] G. Hansel, D. Perrin and I. Simon, Compression and entropy, in Proceedings of STACS'92 - Symposium on Theoretical Aspects of Computer Science, edited by A. Finkel and M. Jantzen. Springer-Verlag, Berlin 577 (1992) 515-528.

[6] J. Karhumäki and I. Simon, A note on elementary homomorphisms and their regularity of equality sets. Bull. Eur. Assoc. Theor. Comput. Sci. 9 (1979) 16-24.

[7] Y. Kohayakawa and I. Simon, editors. Semana de combinatória, in Proceedings of the meeting dedicated to Professor Paul Erdös, São Paulo, Brazil, November 9-11, 1994 (1995).

[8] T. Kowaltowski, C. Lucchesi, I. Simon and J. Simon, Aspectos Teóricos da Computação. Projeto Euclides. Livros Técnicos e Científicos Editora Rio de Janeiro (1979). Prepublished at the occasion of $11^{\circ}$ Colóquio Brasileiro de Matemática, IMPA, Rio de Janeiro (1977).

[9] T. Kowaltowski, V.W. Setzer and I. Simon, Curso de FORTRAN IV básico. Edgard Blücher e Editora da USP, São Paulo (1972). Last edition in (1988), with Editora da Universidade de São Paulo.

[10] T. Kowaltowski and I. Simon, Síntese moderna de filtros no computador, 1a parte. Electron, São Paulo 17 (1966) 233-237.

[11] T. Kowaltowski and I. Simon, Síntese moderna de filtros no computador, 2a parte. Electron, São Paulo 18 (1966) 285-287.

[12] T. Kowaltowski and I. Simon, Cálculo do rastreio superheterodino. Electron, São Paulo 19 (1967) $17-21$.

[13] A. Mandel and I. Simon, On finite semigroups of matrices. Theor. Comput. Sci. 5 (1977/78) $101-111$.

[14] U.S.R. Murty and I. Simon, A $\beta$-function that is not a sum of rank functions of matroids, in Problèmes Combinatoires et Théorie des Graphes (Colloq. Internat. CNRS, Univ. Orsay, Orsay, 1976), Colloq. Internat. CNRS, Paris 260 (1978) 305-306.

[15] B. Pehrson and I. Simon, editors. IFIP'94 - 13th World Computer Congress. North-Holland Publishing Co., Amsterdam (1994).

[16] A. Pereira do Lago and I. Simon, Free Burnside semigroups. Theor. Inform. Appl. 35 (2001) $579-595$.

[17] A. Pereira do Lago and I. Simon, Tópicos em algoritmos sobre seqüências. Publicações Matemáticas do IMPA. [IMPA Mathematical Publications]. Instituto de Matemática Pura e Aplicada (IMPA), Rio de Janeiro, 2003. 24 Colóquio Brasileiro de Matemática. [24th Brazilian Mathematics Colloquium].

[18] J.-E. Pin and I. Simon, A note on the triangle conjecture. J. Combin. Theory Ser. A 32 (1982) 106-109.

[19] J. Sakarovitch and I. Simon, Combinatorics on Words, chapter Subwords, Addison-Wesley, Reading 105-144 (1983).

[20] I. Simon, TAB - Manual de um sistema estatístico. Centro de Computação Eletrônica da Universidade de São Paulo, São Paulo (1969).

[21] I. Simon, On the time required by the Davis-Putnam tautology recognition algorithm. Notices Amer. Math. Soc. 18 (1971) 970.

[22] I. Simon, Hierarchies of Events with Dot-Depth One. PhD Thesis, University of Waterloo, Department of Applied Analysis and Computer Science, Waterloo, Ont., Canada (1972).

[23] I. Simon, Piecewise testable events, in Automata theory and formal languages (Second GI Conf., Kaiserslautern, 1975), edited by H. Brakhage. Springer-Verlag, Berlin 33 (1975) 214-222.

[24] I. Simon, Caracterização de conjuntos racionais limitados. Tese de livre-docência, Instituto de Matemática e Estatística da Universidade de São Paulo, São Paulo (1978).

[25] I. Simon, Limited subsets of a free monoid, in Proceedings of the 19th Annual Symposium on Foundations of Computer Science, IEEE 19 (1978) 143-150.

[26] I. Simon, Some typical problems in graph theory, in Proceedings of the Tenth Brazilian Colloquium (Poços de Caldas, 1975), Vol. II (Portuguese), IMPA - Inst. Mat. Pura Apl., Rio de Janeiro (1978) 355-367.

[27] I. Simon, Conditions de finitude pour des semigroupes. C. R. Acad. Sci. Paris, Sér. A-B 290 (1980) 1081-1082. 
[28] I. Simon, Séminaire d'Informatique Théorique, chapter On Brzozowski's problem: $(1+$ A) ${ }^{m}=A^{*}$, LITP, Paris (1980) 67-72.

[29] I. Simon, Configurações Combinatórias. $13^{\circ}$ Colóquio Brasileiro de Matemática. [13th Brazilian Mathematics Colloquium]. Instituto de Matemática Pura e Aplicada Conselho Nacional de Desenvolvimento Científico e Tecnológico, Rio de Janeiro (1981).

[30] I. Simon, Linguagens Formais e Autômatos. Segunda Escola de Computação, IMECCUNICAMP, Campinas (1981).

[31] I. Simon, Word Ramsey theorems, in Graph theory and combinatorics: a volume in honor of Paul Erdös (Cambridge, 1983). Academic Press, London (1984) 283-291.

[32] I. Simon, Infinite words and a theorem of Hindman. Rev. Mat. Apl. 9 (1988) 97-104.

[33] I. Simon, Recognizable sets with multiplicities in the tropical semiring, in Mathematical foundations of computer science, 1988 (Karlovy Vary, 1988), edited by M.P. Chytil, L. Janiga, and V. Koubek. Springer-Verlag, Berlin, Lect. Notes Comput. Sci. 324 (1988) $107-120$.

[34] I. Simon, Properties of factorization forests, in Formal properties of finite automata and applications (Ramatuelle, 1988), edited by J.-E. Pin. Springer-Verlag, Berlin, Lect. Notes Comput. Sci. 386 (1989) 65-72.

[35] I. Simon, Sequence comparison: some theory and some practice, in Electronic Dictionaries and Automata in Computational Linguistics, edited by M. Gross and D. Perrin. SpringerVerlag, Berlin, Lect. Notes Comput. Sci. 377 (1989) 79-92.

[36] I. Simon, Factorization forests of finite height. Theor. Comput. Sci. 72 (1990) 65-94.

[37] I. Simon, The nondeterministic complexity of a finite automaton, in Mots- mélanges offerts à M. P. Schützenberger, edited by M. Lothaire. Lang. Raison. Calc., Hermès, Paris (1990) 384-400.

[38] I. Simon, Palavras, autômatos e algoritmos, uma bibliografia. Bibliografia (1990). IME-USP, São Paulo.

[39] I. Simon, News from Latin America. Bull. Eur. Assoc. Theor. Comput. Sci. (1991). Quadrimestral regular column.

[40] I. Simon, editor. LATIN'92 - 1st. Latin American Symposium on Theoretical Informatics, Springer-Verlag, Berlin. Lect. Notes Comput. Sci. 583 (1992).

[41] I. Simon, A short proof of the factorization forest theorem, in Tree Automata and Languages (Le Touquet, 1990), edited by M. Nivat and A. Podelski, Stud. Comput. Sci. Artificial Intelligence. North-Holland, Amsterdam 10 (1992) 433-438.

[42] I. Simon, The product of rational languages, in Proceedings of ICALP'93 - International Conference on Automata, Languages and Programming, Berlin 700 (1993) 430-444.

[43] I. Simon, String matching algorithms and automata: extended abstract, in First South American Workshop on String Processing, edited by R. Baeza-Yates and N. Ziviani. Belo Horizonte (1993) 151-157. UFMG.

[44] I. Simon, On semigroups of matrices over the tropical semiring. RAIRO Inform. Théor. Appl. 28 (1994) 277-294.

[45] I. Simon, String matching algorithms and automata, in Results and trends in theoretical computer science (Graz, 1994), edited by J. Karhumäki H. Maurer and G. Rozenberg. Springer-Verlag, Berlin 812 (1994) 386-395.

[46] I. Simon, Von Neumann, o cientista e a figura humana. Estudos Avançados 26 (1996) 179-188.

[47] I. Simon, The tropical semiring and the theory of automata, in Algèbres Max-Plus et applications en informatique et automatique. Annals of the 26th École de printemps d'informatique théorique, Ile de Noirmoutier, Le Chesnay, INRIA (1998) 373-376.

[48] I. Simon, Words distinguished by their subwords. (Extended abstract), in Proceedings of WORDS'O3, the 4th international conference on combinatorics on words, Turku, Finland, September 10-13, 2003, edited by Harju, Tero et al. Turku Centre for Computer Science. TUCS General Publication 27 (2003) 6-13. 


\section{WRITINGS ON THE IMPACT OF THE NEW TECHNOLOGIES OF INFORMATION}

[1] J. Delyra, A. Mandel and I. Simon, A Importância da Ciência para o Desenvolvimento Nacional, chapter Informação: Computação e Comunicação. Academia Brasileira de Ciências, Rio de Janeiro (1997). Reprint of [2].

[2] J. Delyra, A. Mandel and I. Simon, Informação: computação e comunicação. Revista da USP 35 (1997) 11-45.

[3] R.U. Karpischek and I. Simon, Ferramentas computacionais para um esforço cooperativo de digitalização de textos impressos. Submitted for publication.

[4] F.F. Moraes and I. Simon, As novas tecnologias e as universidades milenares. Revista da USP 35 (1997) 7-9.

[5] F.F. Moraes and I. Simon, Computer networks and the internationalization of higher education. Higher Education Policy, Paris 13 (2000) 319-324.

[6] I. Simon, Universidade e Novas Tecnologias: Impactos e Implicações, chapter A universidade diante das novas tecnologias de informação e comunicação, Universidade de São Paulo, Rede Macunaíma do Projeto Alfa, São Paulo (1999) 47-49.

[7] I. Simon, A Propriedade Intelectual na Era da Internet. DataGramaZero 1 (2000). Rio de Janeiro.

[8] I. Simon, A USP e seus Desafios, chapter A Universidade e a Tecnologia da Informação, Editora da Universidade de São Paulo, São Paulo (2001) 275-280.

[9] I. Simon, O Oráculo Bibliográfico: Sonhos de um Pesquisador. Revista da USP 55 (2002) 6-11. 